Article

\title{
Coupled Microbiological-Isotopic Approach for Studying Hydrodynamics in Deep Reservoirs: The Case of the Val d'Agri Oilfield (Southern Italy)
}

\author{
Pietro Rizzo ${ }^{1}$, Antonio Bucci ${ }^{2, * \mathbb{C}}$, Anna Maria Sanangelantoni ${ }^{1}$, Paola Iacumin ${ }^{1}$ \\ and Fulvio Celico ${ }^{1}$ (D) \\ 1 Department of Chemistry, Life Sciences and Environmental Sustainability, University of Parma, Parco Area \\ delle Scienze 157/A, 43124 Parma, Italy; pietro.rizzo2@studenti.unipr.it (P.R.); \\ annamaria.sanangelantoni@unipr.it (A.M.S.); paola.iacumin@unipr.it (P.I.); fulvio.celico@unipr.it (F.C.) \\ 2 Department of Biosciences and Territory, University of Molise, C.da Fonte Lappone, 86090 Pesche, Italy \\ * Correspondence: antonio.bucci@unimol.it; Tel.: +39-0874-404156
}

Received: 31 March 2020; Accepted: 20 May 2020; Published: 22 May 2020

check for updates

\begin{abstract}
The studies upstream of the petroleum industry include oil and gas geological exploration and are usually focused on geological, structural, geophysical, and modeling techniques. In this research, the application of a coupled microbiological-isotopic approach was explored to assess its potential as an adequate characterization and monitoring tool of geofluids in oilfield areas, in order to expand and refine the information acquired through more consolidated practices. The test site was selected within the Val d'Agri oilfield, where some natural hydrocarbon springs have been documented since the 19th century in the Tramutola area. Close to these springs, several tens of exploration and production wells were drilled in the first half of the 20th century. The results demonstrated the effectiveness of the proposed approach for the analysis of fluid dynamics in complex systems, such as oilfield areas, and highlighted the capacity of microbial communities to "behave" as "bio-thermometers", that is, as indicators of the different temperatures in various subsurface compartments.
\end{abstract}

Keywords: hydrocarbon reservoir; groundwater; microbiological investigations; prokaryotes; isotopic investigations; $\delta^{2} \mathrm{H}$ and $\delta^{18} \mathrm{O}$; southern Italy

\section{Introduction}

Petroleum reservoirs are discovered in a wide range of geologic settings across the continents [1] and their monitoring is one of the key factors in the management of oil and gas resources [2]. Successful management requires an understanding of the structure of the reservoir, the distribution of fluids within the reservoir, drilling and maintaining wells which can produce fluids from the reservoir, transport and processing of produced fluids, refining and marketing the fluids, safely abandoning the reservoir when it can no longer produce, and mitigating the environmental impact of operations throughout the life cycle of the reservoir [3].

The studies on mineral oil and gas reservoirs are usually focused on geological, structural, and geophysical features, e.g., [4-8]. In this research, we explore, for the first time, the potential application of a coupled microbiological-isotopic approach as a useful tool for the characterization and monitoring of geofluids in oilfield areas, in order to expand and refine the information acquired through more consolidated practices.

The isotopes, and in particular the analysis of the stable isotopes ${ }^{18} \mathrm{O}$ and ${ }^{2} \mathrm{H}$, allow identifying the origins of groundwater, and their use has long been consolidated in hydrogeological studies, e.g., [9-11]. 
On the other hand, prokaryotes (domains Bacteria and Archaea) have developed a high adaptive capacity in the most different habitats on the planet, and they can colonize even the harshest environments. They dominate global biogeochemical cycles, thus regulating ecosystem functions. Bacteria and archaea are ubiquitous in nature and have often been used to monitor water quality, e.g., [12,13], to increase knowledge of the hydrogeological characteristics of aquifer systems, e.g., [14,15], and to evaluate the potential of bioremediation of contaminated sites, e.g., [16-19]. Besides, over the last decades, broad phylogenetic and functional diverse microbial communities of several subsurface oil reservoirs have been described using the newly available molecular techniques, e.g., [20].

It is well known that only a small fraction of naturally occurring microorganisms can be cultivated in laboratory growth conditions. This has hindered, in the past, the full characterization of ecosystems and precluded the understanding of how they work and are regulated. Metagenomics and other "omics" are among the fastest advancing scientific tools at the basis of the recent and unprecedented access to genetic and functional information of entire microbial communities, contributing to knowledge about mechanisms and processes of essential ecosystem services, and to the emergence of innovative applications in many different areas. For instance, the next-generation sequencing (NGS) of 16S rRNA gene is now one of the most widely used applications for the taxonomic and phylogenetic evaluation of microbial community composition, e.g., [21-23], and it has opened the door to a deeper insight of complex environments.

\section{Materials and Methods}

\subsection{Study Area}

The Val d'Agri is a Quaternary NW-SE trending intramountain basin located within the southern Apennines thrust belt (southern Italy) (Figure 1), whose formation and evolution were controlled by brittle tectonics. The intense and recent deformation is testified by seismic activity in the last $40 \mathrm{ka}$, such as the M7 1857 Basilicata earthquake, e.g., [24-26].

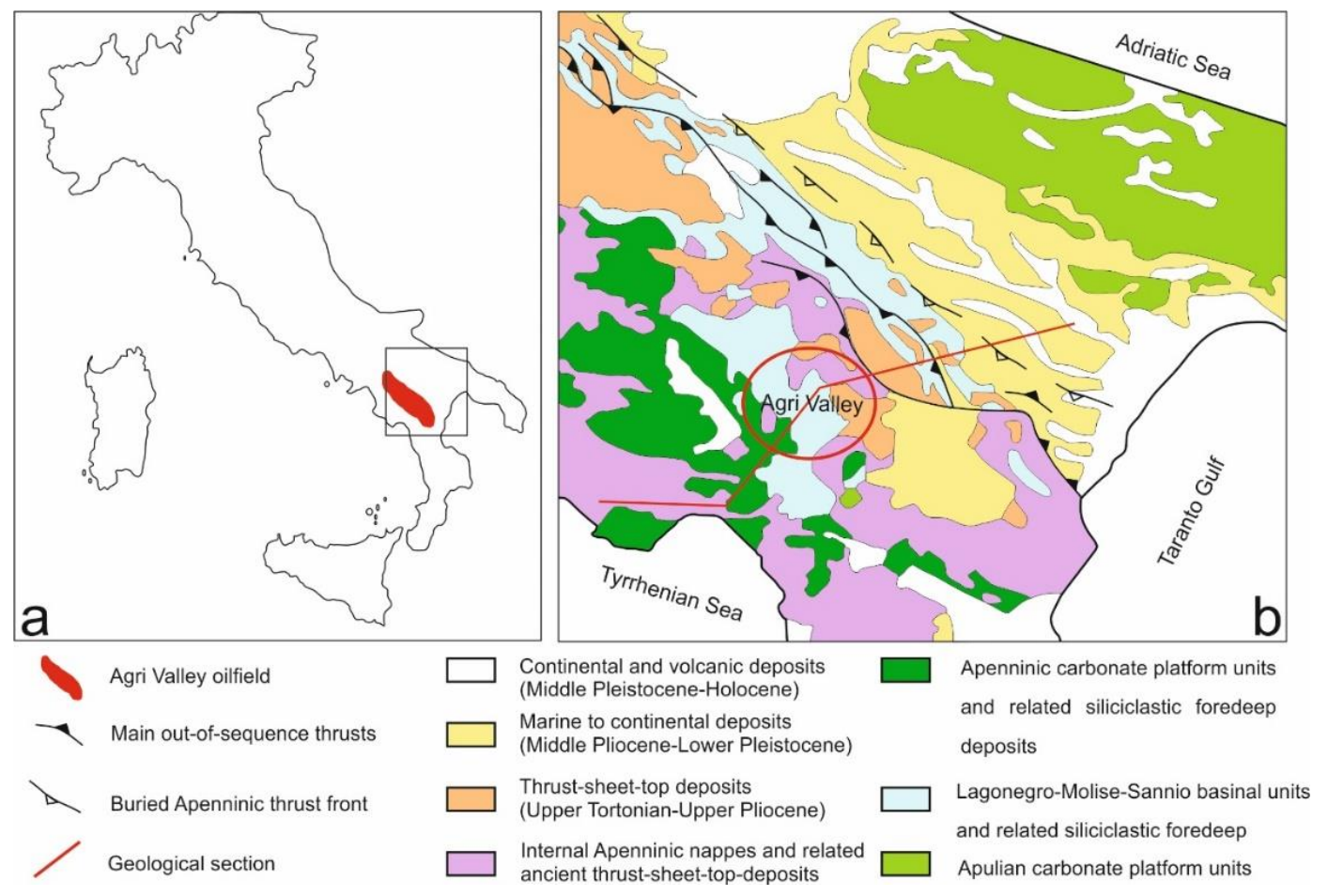

Figure 1. (a) Localization of the study area. (b) Schematic structural-geological map of the southern Apennines from Patacca et al., 1992, modified [27]. 
The main Val d'Agri oilfield is hosted in a reservoir made of fractured, low-porosity carbonates belonging to the buried inner Apenninic Platform belt, e.g., [28-30]. Light to medium crude oil and gas are stored in limestone and dolomite (Miocene to Cretaceous age) [31]. The carbonate reservoir lies below the Pliocene siliciclastic foredeep deposits and a thick mélange layer (Figure 2). Hydrocarbons have been extracted since the mid-1900s through several wells at a depth ranging from 1.8 to $3.5 \mathrm{~km}$ below sea level.

The Apenninic Platform is about $7000 \mathrm{~m}$ thick and characterized by a bottom part made up of evaporites, sandstones, and conglomerates (Triassic age) lying above a crystalline basement. Well data were used to establish the progressive movement of the front of the chain towards the NE during the Pliocene-early Pleistocene.

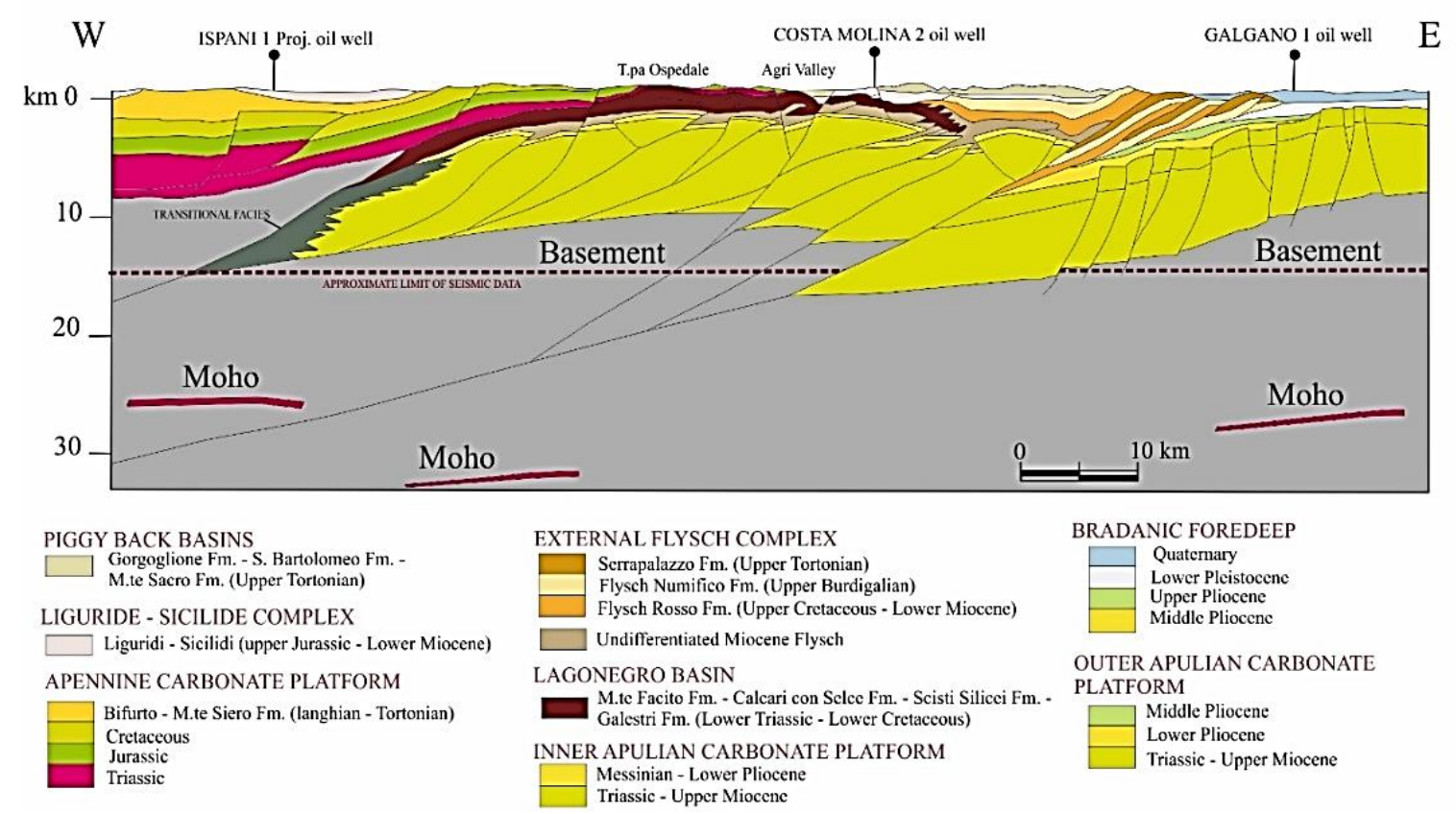

Figure 2. Geological section W-E crossing the Agri Valley from Menardi, Noguera, and Rea 2000, modified [30].

The study area is in Tramutola village. It includes natural hydrocarbon springs whose presence was already known thanks to oral testimonies and several papers published at the end of the 19th century and early 20th century [32]. The hydrocarbon seepages pour in the stream Rio Cavolo, forming oil stains (Figure 3).

From the late nineteenth century onward, research activities led to the discovery of the small and superficial Tramutola oil field exploited by Agip Mineraria in the 1930s and 1940s through 45 exploration and production wells.

These wells intercepted oil and/or gas from a few to several hundreds of meters below the ground (b.g.), e.g., [33]. From one of these wells ( $P_{\text {art }}$, artesian well) and the hydrocarbon springs, hydrogen sulfide $\left(\mathrm{H}_{2} \mathrm{~S}\right)$ emissions occur and are immediately recognizable because of the typical smell of "rotten egg" (unpublished data).

The springs S1 and S2, as well as $\mathrm{P}_{\text {art }}$, are located along a W-E fault where the Apulian carbonate platform and Rio Cavolo Unit (Oligocene) [34] crop out (Figure 4). The $\mathrm{P}_{\text {art }}$ stratigraphy can be schematized as follows (from the top to the bottom): Rio Cavolo Unit from 0 to $44 \mathrm{~m} \mathrm{b.g.,} \mathrm{Apenninic}$ Platform carbonates from 44 to $136 \mathrm{~m} \mathrm{b.g.,} \mathrm{tectonic} \mathrm{mélange} \mathrm{from} 136$ to $165 \mathrm{~m}$ b.g., Flysch Galestrino Formation from 165 to $352 \mathrm{~m}$ b.g., and Scisti Silicei Formation from 352 to $404 \mathrm{~m} \mathrm{b.g.} \mathrm{Oil} \mathrm{and} \mathrm{gas}$ were detected at a different depth within the Rio Cavolo Unit, Flysch Galestrino, and Scisti Silicei Formations [33]. 


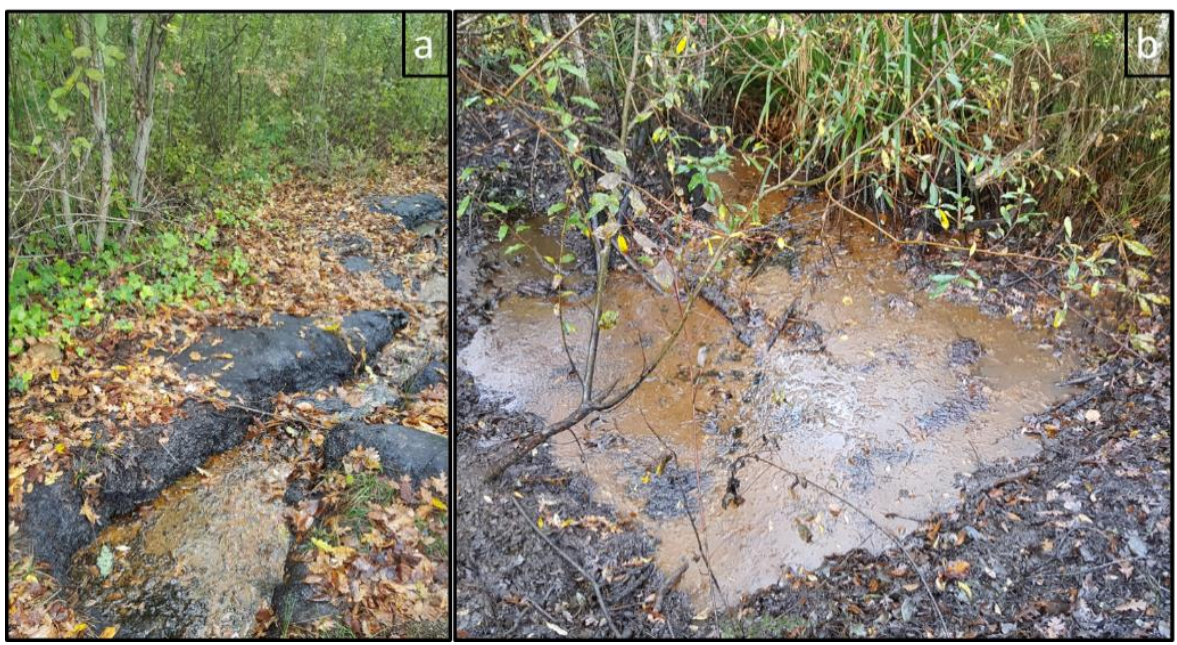

Figure 3. Hydrocarbon springs S1 (a) and S2 (b).



Figure 4. Geological map of the study area; the blue points and the triangle show the location of the investigated springs S1, S2, and S3 and the artesian well $\mathrm{P}_{\text {art }}$ (the geological sketch is taken from Olita 2018, modified [33]).

The Rio Cavolo Unit is made up of clays, micaceous limestone, and rare marly layers. The tectonic mélange is between (overthrust) the Apennine Platform and the Lagonegrese Units [35]. The Flysch Galestrino Formation (Lower Cretaceous) is made up of clays, marls, and limestone, while the Scisti Silicei Formation (Upper Triassic-Jurassic) is composed of clays, marls, and chert [36,37].

From the hydrogeological point of view, the study site belongs to an area where different hydrogeological series complexes crop out. In more detail, the carbonate rocks belong to the so-called Mesozoic carbonate platform series complexes, whose permeability is very high, due to a well-developed fracture network and the presence of karst conduits [38]. The less permeable sedimentary successions belong to the syn-orogenic turbidite series complexes and both the outer and the inner basins series complexes. The rock masses belonging to these complexes are characterized by a permeability ranging from very low to low, due to a mixed pore-fracture network. However, their hydraulic conductivity can be locally enhanced due to well-developed damage zones associated to fault zones [38]. Along the Cavolo stream and the whole Agri Valley, alluvial sediments crop out. Due to the coexistence of fine and coarse sediments, the hydraulic conductivity of the alluvial complex range between less than $1 \times 10^{-8}$ and $2 \times 10^{-2} \mathrm{~m} / \mathrm{s}[39]$.

No detailed studies have been published concerning the hydrogeological behavior of carbonate and siliciclastic media at the study area. However, the same hydrogeological units were deeply investigated and characterized in the wider context of the continental Italian southern Apennines (for siliciclastic low-permeability media, see, for example, Petrella and Celico, 2009 [40]; for high-permeability carbonate 
aquifers, see, for example, Petrella and Celico, 2013 [41], De Vita et al. 2012 [42], Allocca et al. 2015 [43], and Fiorillo et al. 2018 and 2019 [44,45]).

As per groundwater geochemistry in the study area, interesting results were obtained by Paternoster et al. 2005 [46]. The springs fed by carbonate aquifers have a $\mathrm{Ca}-\mathrm{HCO}_{3}$ composition, while groundwaters flowing within the siliciclastic sediments have a high amount of As and $\mathrm{Cu}$. However, the concentrations of As and first-row transition elements were usually below the maximum permissible level for drinking water defined by Italian law. The authors link the availability of $\mathrm{As}, \mathrm{Pb}$, $\mathrm{Cu}, \mathrm{Zn}$, and $\mathrm{Fe}$ to the occurrence of iron oxi-hydroxides. Moreover, nitrate concentration seems to be influenced by the use of fertilizers.

\subsection{Hydrogeological Investigations}

The discharges of the hydrocarbon springs S1 and S2 were measured in low flow (July 2018), in early recharge (October 2018) and in late recharge (March 2019). The flow rate of the $P_{\text {art }}$ artesian well was not measurable, but based on some historical data, its order of magnitude is about $30 \mathrm{~m}^{3} / \mathrm{h}$ (unpublished data).

\subsection{Water Sampling and Analyses}

Three sampling campaigns have been carried out in July 2018, October 2018, and March 2019.

Rainwater samples for isotopic analyses were collected monthly in two local rain samplers located at 1047 and $1290 \mathrm{~m}$ above sea level (a.s.l.).

The rainfall was collected using ten-liter polyethylene bottles containing about $300 \mathrm{~mL}$ of vaseline oil to prevent evaporation processes. Oil contamination was carefully avoided by syringing the water samples out of the bottle.

Ground water samples for stable isotope $\left(\delta^{18} \mathrm{O}, \delta^{2} \mathrm{H}\right)$, tritium, and microbiological (Next-Generation Sequencing of $16 \mathrm{~S}$ rRNA gene) analyses were collected during the discharge measurements at springs $\mathrm{S} 1$ and $\mathrm{S} 2$, and at the $\mathrm{P}_{\text {art }}$ well (screened at the well bottom).

The non-hydrocarbon spring S3, fed by the local carbonate aquifer and located at the contact between the high-permeability carbonate rocks and low-permeability siliciclastic successions, was analyzed for its isotopic content and used as a sort of endmember to compare hydrocarbon spring water with groundwater exclusively flowing within a relatively shallow aquifer system.

The localization of the rain samplers, springs, and the artesian well is reported in Table 1.

In addition, a water sample was also collected from the deep reservoir and analyzed to compare its isotopic signature and microbial community with those retrieved in the spring and $\mathrm{P}_{\text {art }}$ groundwaters.

Electrical conductivity, temperature, and $\mathrm{pH}$ measurements were performed in situ with portable equipment (Hanna Instruments 9829).

All samples were stored in a refrigerated box and transported to the laboratory.

Stable isotope analyses $\left(\delta^{18} \mathrm{O}, \delta^{2} \mathrm{H}\right)$ were carried out at the Isotope Geochemistry Laboratory of the University of Parma (Italy), using a Delta Plus mass spectrometer (Thermo Fisher Scientific, Waltham, Massachusetts, USA) coupled to an automatic HDO device preparation system. The technique consists of bringing the liquid sample into an isotopic equilibrium, at a controlled temperature of $18{ }^{\circ} \mathrm{C}$, with a pure gas $\left(\mathrm{CO}_{2}\right.$ in the case of oxygen and $\mathrm{H}_{2}$ in the case of hydrogen). The isotopic equilibrium, in the case of hydrogen, would be reached very slowly, and platinum catalysts are used to accelerate the reaction. For the oxygen isotope determination, $5 \mathrm{~cm}^{3}$ of water was equilibrated with pure $\mathrm{CO}_{2}$, while for hydrogen isotopes, $5 \mathrm{~cm}^{3}$ of water was equilibrated with pure $\mathrm{H}_{2}$ (platinum wire was used as a catalyzer of gas-liquid water equilibration). Equilibration times were $3 \mathrm{~h}$ for hydrogen and $8 \mathrm{~h}$ for oxygen. The isotope ratio is expressed as

$$
{ }^{\mathrm{A} / \mathrm{B}} \delta_{\mathrm{i} / \mathrm{RF}}=\frac{\mathrm{A} / \mathrm{B} \mathrm{R}_{\mathrm{i}}}{\mathrm{A} / \mathrm{B} \mathrm{R}_{\mathrm{VSMOW}-\mathrm{SLAP}}}-1=\left[\left(\frac{\mathrm{A} / \mathrm{B} \mathrm{R}_{\mathrm{i}}}{\mathrm{A} / \mathrm{B} \mathrm{R}_{\mathrm{VSMOW}-\mathrm{SLAP}}}-1\right) 10^{3}\right] \%
$$


where " $\mathrm{A}$ " is 18 or 2, " $\mathrm{B}$ " is 16 or 1 , " $\mathrm{R}$ " is the ratio of the isotopic abundances, " $\mathrm{i}$ " is the sample of interest, and \%o $=10^{-3}$. Analyses of ${ }^{3} \mathrm{H}$ were carried out at the Isotope Geochemistry Laboratory of Trieste University, Italy. To decrease measurement errors, the samples followed the procedure of the preventive electrolytic enrichment of tritium, where $250 \mathrm{~g}$ of the water sample was expected to be reduced, by electrolysis, to $20 \mathrm{~g}$. The analyses for the determination of the tritium activity were carried out according to the procedures provided by Water and Environment News No. 3 (1998) [47]. The analytical prediction uncertainty was $\pm 0.1 \%$ for $\delta^{18} \mathrm{O}, \pm 1 \%$ o for $\delta^{2} \mathrm{H}$, and \pm 0.5 TU for ${ }^{3} \mathrm{H}$.

Table 1. The coordinates expressed in Latitude N, Longitude E, and the altitude of the two rain samplers (RWS1 and RWS2), springs, and the artesian well.

\begin{tabular}{cccc}
\hline Name & Latitude N & Longitude E & Altitude (m a.s.1.) \\
\hline RWS1 & 40.3247 & 15.9897 & 1047 \\
RWS2 & 40.3411 & 16.0003 & 1290 \\
S1 & 40.3225 & 15.7597 & 636 \\
S2 & 40.3228 & 15.7586 & 643 \\
S3 & 40.3175 & 15.7594 & 643 \\
$P_{\text {art }}$ & 40.3225 & 15.7592 & 643 \\
\hline
\end{tabular}

\subsection{Chemical Analyses}

During the third sampling campaign in March 2019, water samples were collected from the hydrocarbon springs and the well, $\mathrm{P}_{\text {art }}$, to analyze Benzene, Toluene, Ethylbenzene, Xylene (BTEX) and Polycyclic aromatic hydrocarbons (PAHs) contents. Forty milliliter colorless glass vials were used for the BTEX analysis, while 1 L black glass bottles were used for PAH analysis. The analyses were performed at Biochemie Lab S.r.l. following the EPA 5030C 2003 + EPA 8015D 2003 protocol for BTEX and the EPA3510C 1996 + EPA 8270E 2018 protocol for PAH [48-51].

\subsection{Microbiological Analyses: $16 S$ Ribosomal RNA Gene Next Generation Sequencing (NGS)}

For bacterial community analyses, water samples $(4 \mathrm{~L})$ were filtered through sterile mixed esters of cellulose filters (S-Pak ${ }^{\mathrm{TM}}$ Membrane Filters, $47 \mathrm{~mm}$ diameter, $0.22 \mu \mathrm{m}$ pore size, Millipore Corporation, Billerica, MA, USA) within $24 \mathrm{~h}$ from the collection. Bacterial DNA extraction from filters was performed using the commercial kit FastDNA SPIN Kit for soil and FastPrep ${ }^{\circledR}$ Instrument. After the extraction, DNA integrity and quantity were evaluated by electrophoresis in $0.8 \%$ agarose gel containing $1 \mu \mathrm{g} / \mathrm{mL}$ of Gel-RedTM. The bacterial community profiles in the samples were generated by NGS technologies at the Genprobio S.r.l. Laboratory. Partial 16S rRNA gene sequences were obtained from the extracted DNA by polymerase chain reaction (PCR), using the primer pair Probio_Uni and Probio_Rev, targeting the V3 region of the bacterial 16S rRNA gene sequence [52]. Amplifications were carried out using a Verity Thermocycler (Applied Biosystems) and PCR products were purified by the magnetic purification step involving the Agencourt AMPure XP DNA purification beads (Beckman Coulter Genomics GmbH, Bernried, Germany) in order to remove primer dimers. Amplicon checks were carried out as previously described [52]. Sequencing was performed using an Illumina MiSeq sequencer with MiSeq Reagent Kit v3 chemicals. The fastq files were processed using a custom script based on the QIIME software suite [53]. Paired-end read pairs were assembled to reconstruct the complete Probio_Uni/Probio_Rev amplicons. Quality control retained sequences with a length between 140 and $400 \mathrm{bp}$ and mean sequence quality score $>20$ while sequences with homopolymers $>7 \mathrm{bp}$ and mismatched primers were omitted. To calculate downstream diversity measures, operational taxonomic units (OTUs) were defined at 100\% sequence homology using DADA2 [54]; OTUs not encompassing at least two sequences of the same sample were removed. All reads were classified to the lowest possible taxonomic rank using QIIME2 [53,55] and a reference dataset from the SILVA database v132 [56]. The biodiversity of the samples (alpha-diversity) was calculated with the Shannon index. 


\section{Results}

\subsection{Hydrogeological Settings}

The discharge of the spring S1 varied slightly over time, showing a slight decrease $\left(1.4\right.$ to $\left.1.3 \mathrm{~m}^{3} / \mathrm{h}\right)$ from July to late October (dry period), and an increase (1.3 to $1.7 \mathrm{~m}^{3} / \mathrm{h}$ ) in March (rainy period), in agreement with the distribution of precipitation in that area. The overall synchronicity between rainy periods and the increase in discharge at S1 clearly suggested active pathways within the feeding aquifer system. Unfortunately, the S2 discharge was not measurable after the winter period, therefore no speculation can be formulated concerning recharge processes.

\subsection{Isotope Investigations}

Monthly values for local precipitation for the period May 2016-April 2017 give the following regression ${ }^{2} \delta$ on ${ }^{18} \delta$ (LMWL, Local Meteoric Water Line):

$$
\begin{gathered}
{ }^{2 / 1} \delta=\left[6.48( \pm 0.66)^{18 / 16} \delta+4.6( \pm 5.2)\right] \% \text { o } \\
\mathrm{s}(\mathrm{yx})=4.56 \% \text { o, } \mathrm{n}=21 \quad \mathrm{p}(\mathrm{A}=0)=0.39
\end{gathered}
$$

where "s(yx)" is the standard error of regression and " $\mathrm{n}$ " is the number of couples of data, " $\mathrm{A}$ " is the intercept of the regression line, and $\mathrm{p}=$ probability.

For precipitation in Southern Italy [57], the resulting regression line is

$$
\begin{gathered}
2 / 1 \delta=\left[6.97( \pm 0.10){ }^{18 / 16} \delta+7.32( \pm 0.61)\right] \% \text { o } \\
\mathrm{s}(\mathrm{yx})=3.75 \% \text { o, } \mathrm{n}=317 \mathrm{p}(\mathrm{A}=0)<<0.0001
\end{gathered}
$$

According to Zar [58], equation (2) may be compared with equation (3) both for the slope (B) and the elevation (E). Note that elevation indicates the different vertical position on the graph. A comparison gives the following results: $\mathrm{p}\left(\mathrm{B}_{(1)}=\mathrm{B}_{(2)}\right)=0.39, \mathrm{p}\left(\mathrm{E}_{(1)}=\mathrm{E}_{(2)}\right)=0.27$. The null hypotheses $\mathrm{H}_{\mathrm{o}}: \mathrm{B}_{(1)}=\mathrm{B}_{(2)}$ and $\mathrm{H}_{\mathrm{o}}: \mathrm{E}_{(1)}=\mathrm{E}_{(2)}$ cannot be rejected with high probability; thus we assume that the two regressions are not different.

The isotopic data of spring and groundwaters collected in the Tramutola study area are located close to the local meteoric water line (2) suggesting a meteoric origin of the analyzed waters (Figure 5). On the contrary, the samples taken from the deep reservoir are far from the line (Figure 5); actually, they represent fossil waters that also interacted with the carbonate formation at an elevated temperature.

The isotopic composition of spring and groundwater samples did not vary widely over time; isotopic variations were lower than $2 \mathrm{u}$, where " $\mathrm{u}$ " is prediction uncertainty for the $\delta^{18} \mathrm{O}$ and $\delta^{2} \mathrm{H}$ data.

As far as tritium is concerned, all samples showed a relatively high ${ }^{3} \mathrm{H}$ content (4.1 to 9.1 TU), if compared with tritium content in recent rainwaters analyzed in southern Italy (e.g., 4.6 TU [59]; 5.0 TU [10]; 6.2 to 10.8 [unpublished data]) and the wider Adriatic area [60]. The non-hydrocarbon spring, S3, was characterized by the highest tritium value (8.4 to $9.1 \mathrm{TU}$ ), in agreement with the rapid pathways within the carbonate aquifer. Moreover, the variation of TU values was lower than $2 \mathrm{u}$, suggesting little interaction with waters having quite different TU values. The hydrocarbon springs S1 and S2 had similar tritium contents (5.6 to 6.9 TU and 6.8 to 7.5 TU, respectively), slightly lower than those characterizing the S3 spring water. As for S1 water, the variation over time was slightly higher than the $2 \sigma$ error of the ${ }^{3} \mathrm{H}$ analyses, therefore suggesting the mixing of different endmembers, possibly related to longer (lower tritium content) and shorter (higher tritium content) pathways. Taking into consideration the homogeneous stable isotope content over time, both pathways are related to well-mixed groundwater. $P_{\text {art }}$ waters showed a more significant variation over time (4.1 to 6.2 TU), further confirming the existence of mixing between different endmembers: (i) one related to rainwater infiltrating relatively far from the observation well and (ii) a second one linked to closer pathways. 


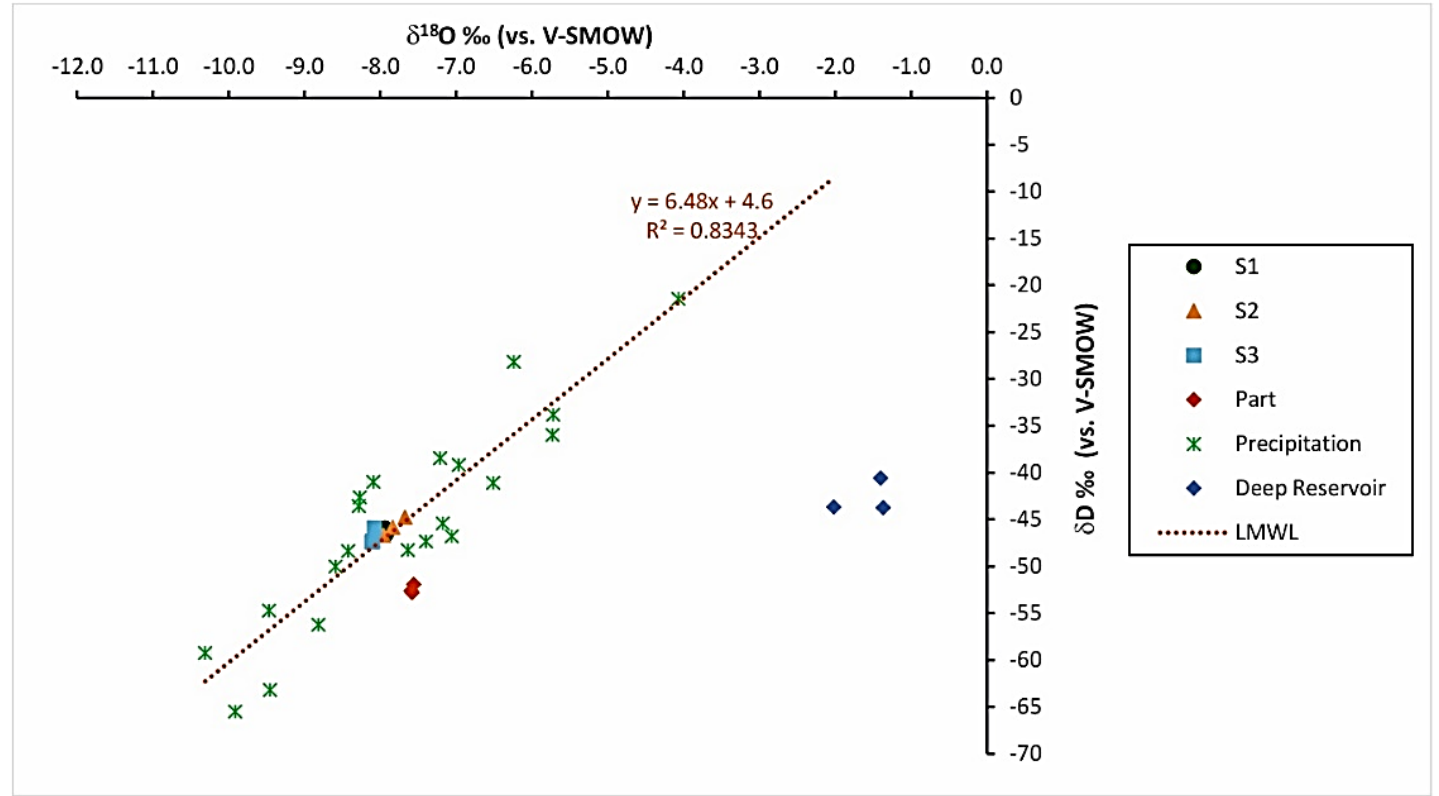

Figure 5. $\delta^{18} \mathrm{O}$ versus $\delta^{2} \mathrm{H}$ relationship in water samples collected from rainwater samplers, at springs $(\mathrm{S} 1 ; \mathrm{S} 2 ; \mathrm{S} 3)$, at the artesian well $\left(\mathrm{P}_{\text {art }}\right)$, and in the deep reservoir. LMWL is the local meteoric water line obtained by local rainwater.

\subsection{Chemical Analyses}

Chemical analyses were performed on springs S1, S2, and well $\mathrm{P}_{\text {art. }}$ Samples collected at the spring S3, whose waters are used for drinking purposes, were not considered for BTEX and PAHs determinations. The data revealed detectable PAH such as naphtalene $(0.00231 \mu \mathrm{g} / \mathrm{L})$ in the spring $\mathrm{S} 1$, and benzo(b)fluoranthene $(0.354 \mu \mathrm{g} / \mathrm{L})$, benzo(k)fluoranthene $(0.0341 \mu \mathrm{g} / \mathrm{L})$, benzo $(\mathrm{g}, \mathrm{h}, \mathrm{i})$ perylene $(0.199 \mu \mathrm{g} / \mathrm{L})$, indene $(0.101 \mu \mathrm{g} / \mathrm{L})$, anthracene $(0.726 \mu \mathrm{g} / \mathrm{L})$, phenanthrene $(0.465 \mu \mathrm{g} / \mathrm{L})$, fluoranthene $(0.166 \mu \mathrm{g} / \mathrm{L})$, and benzo(J)fluoranthene $(0.0140 \mu \mathrm{g} / \mathrm{L})$ in the spring S2. BTEX were not detected in either spring. Neither PAH nor BTEX were detected in groundwater sampled from $\mathrm{P}_{\text {art }}$.

\subsection{Next-Generation Sequencing Results}

MiSeq runs produced an average of 61,682 sequences for the samples collected at the springs (S1 and S2) and from the artesian well, $\mathrm{P}_{\text {art }}$. An average of 80,061 reads was obtained from the analysis of the deep reservoir bacterial community (Table 2). The $16 \mathrm{~S}$ rRNA gene sequences generated in this study have been deposited in the NCBI Sequence Read Archive under the accession number PRJNA629324.

The rarefaction analysis (a measure used to estimate the alpha diversity in samples and gauge whether or not sequencing efforts captured the microbial diversity) highlighted a greater microbial diversity in the spring S2 compared to the spring S1, the artesian well, and the deep reservoir (Figure S1).

Table 2. Number of $16 \mathrm{~S}$ rDNA sequences obtained after NGS analysis for the three sampling campaigns (n.a. is not available).

\begin{tabular}{cccc}
\hline Sample & \multicolumn{3}{c}{ Final Read Number } \\
& \multicolumn{3}{c}{ Sampling Campaigns } \\
\cline { 2 - 4 } & 19 July 2018 & 29 October 2018 & 18 March 2019 \\
\hline S1 & 73,995 & 59,369 & 49,512 \\
S2 & 93,820 & 57,630 & 61,065 \\
$P_{\text {art }}$ & n.a. & 44,730 & 53,341 \\
Deep reservoir & 101,690 & 60,563 & 77,931 \\
\hline
\end{tabular}


Proteobacteria, Chloroflexi, and Bacteroidetes were the three major phyla in waters from the spring S1 in July 2018 (85.55\% of sequences). In October 2018 and March 2019, Epsilonbacteraeota were found with the highest percentages (72.25\% and 52.48\%, respectively) ahead of Proteobacteria (25.78\% and $20.67 \%$ ) and Bacteroidetes $(0.86 \%$ and $23.63 \%)$.

Spring S2 bacterial communities were dominated by Proteobacteria (mean relative abundance $62.86 \%$ ). Actinobacteria occurred at percentages ranging from $3.17 \%$ to $22.23 \%$. In addition, Bacteroidetes (5.51\%), Acidobacteria (8.11\%), and Patescibacteria (4.51\%) were among the three most abundant phyla in July 2018, October 2018, and March 2019, respectively.

Microbial communities in groundwater collected from the $\mathrm{P}_{\text {art }}$ well were mainly characterized by Proteobacteria and Patescibacteria, with mean relative abundance values of $92.78 \%$ and $4.09 \%$, respectively.

The phyla Proteobacteria, Synergistetes, and Firmicutes accounted for, on average, 94.82\% of the sequences retrieved from the deep reservoir. Overall, Proteobacteria represented the dominant phylum in all the samples collected from July 2018 to March 2019, ranging from 42.65\% to 50.88\%.

The analysis of the microbial community composition at the family level (Figure 6) revealed, in spring S1, a predominance of Helicobacteraceae $(47.12 \%)$, Chlorobiaceae $(7.63 \%)$, and unclassified microorganisms of the order Chloroflexales (6.91\%) in July 2018. The top three dominant families were Sulfurovaceae (63.38\%), Halothiobacillaceae $(24.75 \%)$, and Thiovulaceae $(8.46 \%)$ in October 2018, and Sulfurovaceae (31.06\%), Chlorobiaceae (22.56\%), and Thiovulaceae (20.61\%) in March 2019.

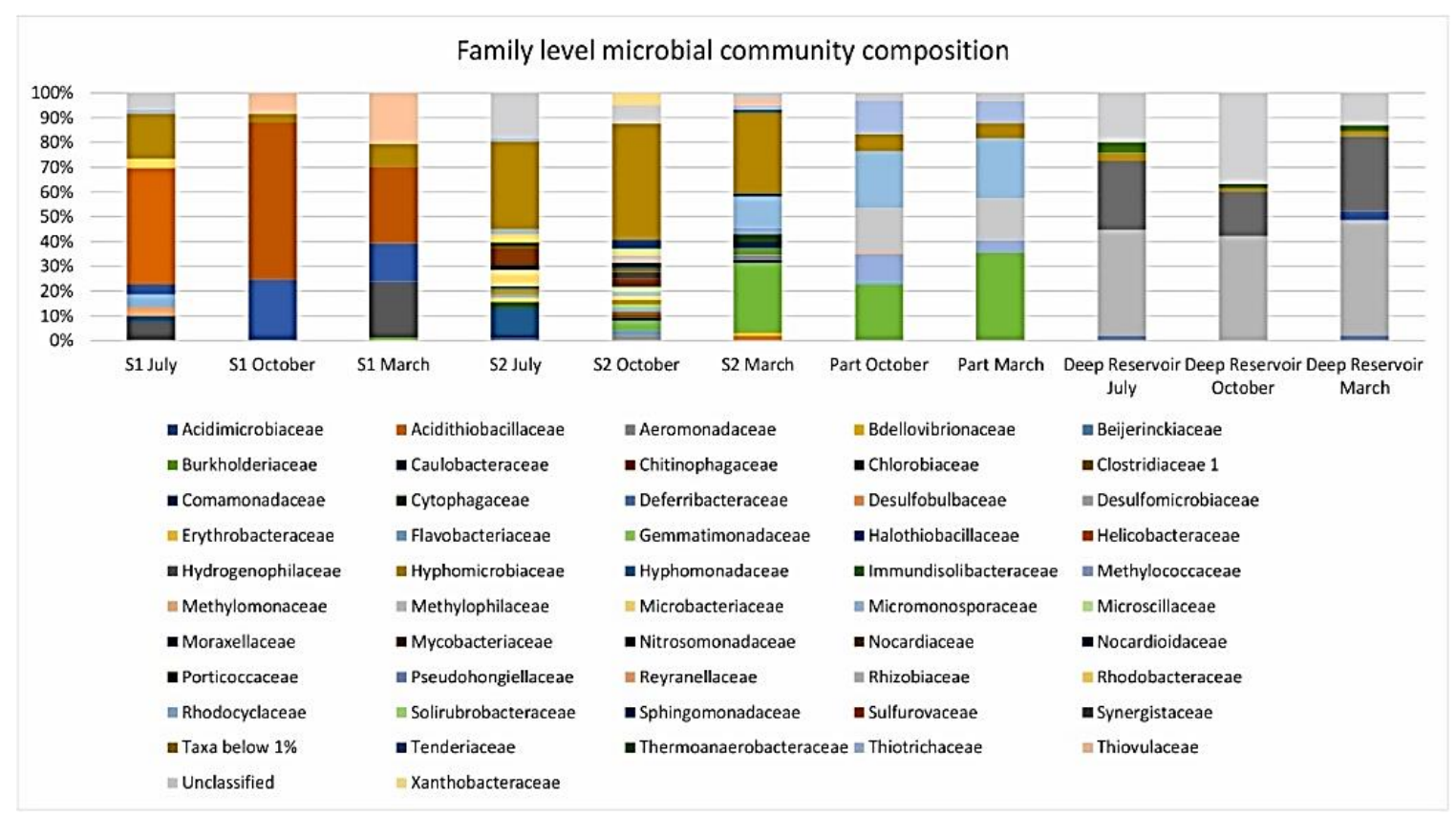

Figure 6. Family level microbial community composition in samples collected from springs, the $\mathrm{P}_{\text {art }}$ well, and the deep reservoir.

The most abundant families in spring S2 were: Comamonadaceae (11.12\%), KCM-B-112 (7.56\%), and Mycobacteriaceae (7.17\%) in July 2018, Xanthobacteraceae (4.96\%), Burkholderiaceae (3.96\%), and unclassified microorganisms of the subgroup 6 class of the Acidobacteria phylum (3.84\%) in October 2018, and Burkholderiaceae (28.28\%), Rhodocyclaceae (12.59\%), and Porticoccaceae (2.99\%) in March 2019.

The bacterial communities of the $\mathrm{P}_{\text {art }}$ well were mainly characterized by the families Burkholderiaceae, Rhodocyclaceae, and Methylophilaceae, accounting for, on average, 29.16\%, 23.49\%, and $17.34 \%$ of sequences, respectively. 
Desulfomicrobiaceae, Synergistaceae, and family III of the order Thermoanaerobacterales were found at the highest percentages in the deep reservoir, with mean values of $43.97 \%, 25.49 \%$, and $20.19 \%$, respectively.

At a lower taxonomic level, spring and groundwaters were mostly characterized by genera (Table 3) including aerobic, microaerophilic, facultative anaerobic, and anaerobic species, mainly mesophilic and psychrophilic, such as, Chelatococcus asaccharovorans [61], Vitreoscilla filiformis [62], Actinoplanes ferrugineus [63], Sphaerotilus natans [64], Hydrogenophaga taeniospiralis [65], and Sphingomonas yunnanensis [66].

Many of these genera encompass chemolithotrophic or phototrophic sulfur-oxidizing bacteria (SOB), which derive energy from the oxidation of reduced sulfur compounds, or use sulfide as electron donors for anoxygenic photosynthesis, like the green sulfur bacterium Chlorobium limicola [67], playing an important role in the element cycling in the environment. These results are not surprising, especially when considering the hydrogen sulfide emissions from the analyzed well and springs. In fact, the presence of this gas in waters, probably naturally generated in situ from reservoir biomass and sulfate-containing minerals through microbial sulfate reduction and/or thermochemical sulfate reduction, could have represented a driving factor shaping microbial community structure and function.

In the deep reservoir, anaerobic and thermophilic microorganisms belonging to the genera Acetomicrobium (e.g., Acetomicrobium thermoterrenum [68]), Desulfomicrobium (e.g., Desulfomicrobium thermophilum [69]), Thermoanaerobacterium (e.g., Thermoanaerobacterium thermosaccharolyticum [70]), and Thermoanaerobacter (e.g., Thermoanaerobacter ethanolicus [71]) with optimum growth temperatures in the range of $55-69{ }^{\circ} \mathrm{C}$, were detected. The genus Acetomicrobium was found in October 2018 and March 2019 with a mean relative abundance of $13.01 \%$, whereas the genera Desulfomicrobium, Thermoanaerobacterium, and Thermoanaerobacter occurred, on average, at percentages of $43.96 \%, 18.30 \%$, and $2.07 \%$, respectively.

Table 3. Main bacterial genera identified in the $\mathrm{P}_{\text {art }}, \mathrm{S} 1$, and $\mathrm{S} 2$ samples. Growth temperatures of some of the species belonging to the different genera are reported.

\begin{tabular}{ccc}
\hline Taxonomy & Growth Temperature $\left({ }^{\circ} \mathbf{C}\right)$ & Citations \\
\hline Actinoplanes & $10-35$ & {$[63]$} \\
Aeromonas & $5-25$ & {$[72]$} \\
Chlorobium & $25-30$ & {$[67]$} \\
Dechloromonas & 25 & {$[73]$} \\
Flavobacterium & $15-30$ & {$[74]$} \\
Hydrogenophaga & 30 & {$[65]$} \\
Leptothrix & $10-37$ & {$[75]$} \\
Methylotenera & $10-34$ & {$[76]$} \\
Microvirga & 37 & {$[77]$} \\
Sphaerotilus & $25-40$ & {$[64]$} \\
Sphingomonas & 28 & {$[66]$} \\
Sulfuricurvum & 25 & {$[78]$} \\
Sulfuritalea & $10-32$ & {$[79]$} \\
Sulfurovum & $10-40$ & {$[80]$} \\
Thiovirga & 30 & {$[81]$} \\
Thiothrix & $20-37$ & {$[82]$} \\
\hline
\end{tabular}

\section{Discussion and Conclusions}

Both the hydrogeological behavior and the isotopic features of the studied hydrocarbon springs suggest that they are strictly related to active recharge in a local aquifer system, in agreement with findings related to the nearby non-hydrocarbon spring, whose waters are used for drinking purposes. At the same time, the hydrocarbon springs flow out along a fault zone, which enhances fluid flow, allowing the upflow of hydrocarbons and their mixing with the local groundwater, which is reasonably fed by the nearby carbonate aquifer. In detail, this is due to the fault crossing the sequence made 
of the Scisti Silicei Formation, Galestri Formation, Tectonic Mélange, Apenninic Carbonate platform, and Rio Cavolo Formation, characterized by oil and gas layers at different depths [33]. The hydraulic behavior of this fault zone is similar to that of faults present in other carbonate aquifers in southern Italy, where the existence of high-permeability damage zones, e.g., [83-85] and/or heterogeneous fault cores, allowing a significant fluid migration, has been revealed in previous research, e.g., [86-93]. In these contexts, bacterial cell filtration typical of low-permeability fine-grained media, e.g., [90,94-97] is limited, and microorganisms can be used effectively as bio-tracers for specific hydrogeological and microbiological purposes, e.g., [97].

The groundwater intercepted by the $\mathrm{P}_{\text {art }}$ well is also fed by a more prolonged pathway, as demonstrated by the tritium content lower than those detected in the hydrocarbon springs and S3. Taking into consideration the wider geological setting, the artesian well intercepted a relatively deep (compatible with mesophilic and psychrophilic bacteria), but active pathway within the Scisti Silicei aquifer (Figure 7). This aquifer is unconfined upgradient and downgradient with respect to the $P_{\text {art }}$ well, where the Scisti Silicei Formation crops out. Differently, it is confined (and locally artesian) where the Scisti Silicei is beneath the low-permeability flysch deposits. This deep groundwater naturally flows eastwards, towards the alluvial aquifer of the Agri Valley.

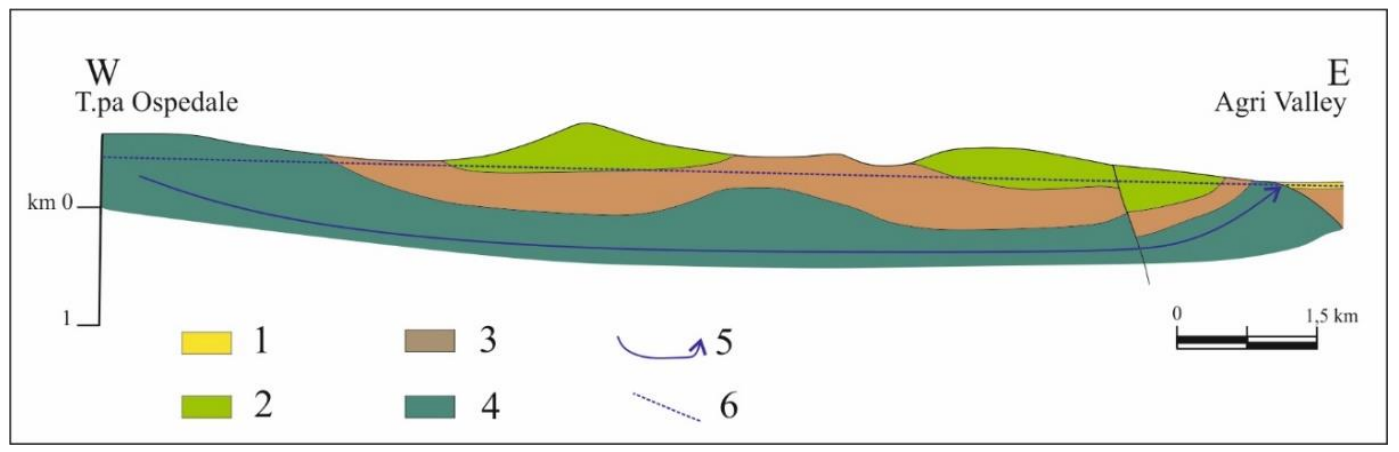

Figure 7. Hydrogeological sketch of the Scisti Silicei aquifer (based on the geological section of Menardi, Noguera, and Rea 2000 [30]). (1) alluvial complex; (2) carbonate complex; (3) low-permeability complex; (4) Scisti Silicei complex; (5) groundwater flow line; (6) hydraulic head.

In the present study, the potential of a coupled microbiological-isotopic approach for monitoring geofluids in hydrocarbon reservoirs and, in detail, the capacity of microbial communities to "behave" as "bio-thermometers", has been assessed for the first time.

When analyzing the communities in the $\mathrm{P}_{\text {art }}$ waters, collected at about $400 \mathrm{~m}$ b.g., and in spring waters, only mesophilic and psychrophilic microorganisms were detected. Differently, in the deep reservoir, thermophilic bacteria thriving at high temperatures, were found. These findings are consistent with geothermal curves and isotherms reported by Candela et al. [98] at the Val d'Agri oilfield (Figure 8), and demonstrate the usefulness of the proposed approach, at least at the study site.

The development and application of molecular biological methods to hydrogeological issues has led to increasing numbers of studies on the microbial communities of aquifer systems over the past few decades, e.g., $[90,97]$. For example, in the carbonate environments of southern Italy, the potential use of microorganisms as tracers has been examined with reference to the analysis of recharge and flow processes with excellent results, e.g., [90,97]. At the study site, the analysis of bacterial species in spring, groundwater, and deep reservoir samples and isotopic analyses proved to be an effective tool to obtain information on the subsurface dynamics and temperatures (Figure 8). In a broader perspective, the same approach could also be used for the comprehension of more complex phenomena in exploited oil fields. 


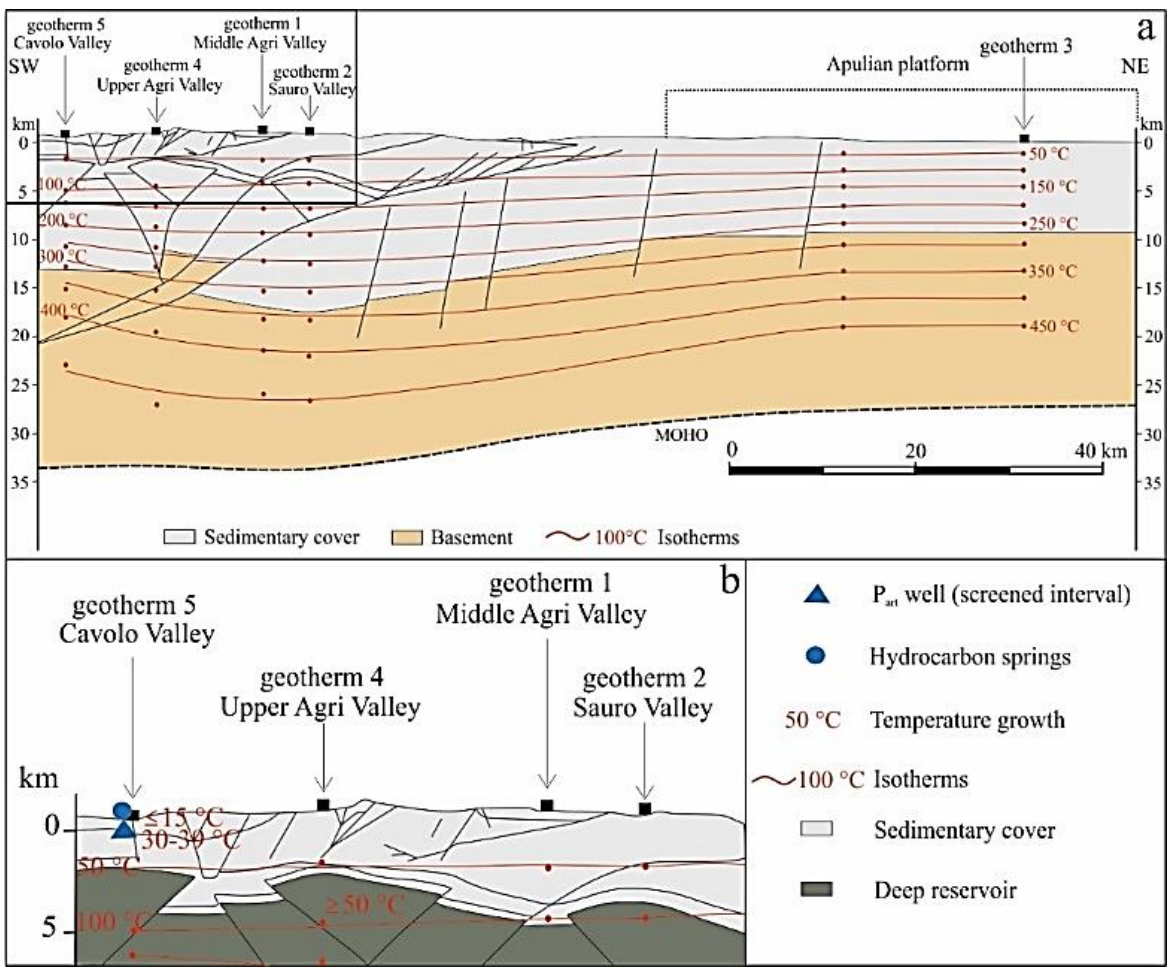

Figure 8. (a) Geological cross-section showing isotherms obtained from the interpolation of geothermal profiles through third-degree polynomials. Red dots show temperatures along the geotherm profiles (50 ${ }^{\circ} \mathrm{C}$ steps). (b) Detail of Figure 8a. Numbers in red show the growth temperature ranges of psychrophilic, mesophilic, and thermophilic microorganisms. Springs (blue point), the well $\mathrm{P}_{\text {art }}$ (blue triangle), and the deep reservoir (in grey) are shown (from Candela et al. 2015, modified [98]).

Supplementary Materials: The following material is available online: http://www.mdpi.com/2073-4441/12/5/ 1483/s1, Figure S1: Rarefaction curves of spring, groundwater, and deep reservoir samples collected in July 2018, October 2018, and March 2019. The alpha diversity plots were obtained by using the Shannon index.

Author Contributions: Conceptualization, A.B., A.M.S. and F.C.; Formal analysis, P.R.; Investigation, P.R.; Supervision, A.B., A.M.S., P.I. and F.C.; Validation, P.R.; Visualization, P.R.; Writing-original draft, P.R. and A.B.; Writing-review \& editing, P.R., A.B., A.M.S., P.I. and F.C. All authors have read and agreed to the published version of the manuscript.

Funding: This research received no external funding

Acknowledgments: We warmly acknowledge Dario Avagliano, Francesco Coraggio, Antonella Caputi, and Fabrizio Micucci (ENIS.p.A., Distretto Meridionale) for providing some of the data used in the present work and for useful discussions. This work has benefited from the equipment and framework of the COMP-HUB Initiative, funded by the "Departments of Excellence" program of the Italian Ministry for Education, University and Research (MIUR, 2018-2022). We are grateful to the reviewers for their constructive comments and valuable suggestions.

Conflicts of Interest: There are no conflicts of interest related to this paper.

\section{References}

1. Satter, A.; Iqbal, G.M. Oil and gas recovery methods in low permeability and unconventional reservoirs. In Reservoir Engineering-The Fundamentals, Simulation, and Management of Conventional and Unconventional Recoveries; Gulf Professional Publishing: Houston, TX, USA, 2016; pp. 353-364.

2. Djuraev, U.; Jufar, S.R.; Vasant, P. A review on conceptual and practical oil and gas reservoir monitoring methods. J. Petrol. Sci. Eng. 2017, 152, 586-601. [CrossRef]

3. Fanchi, J.R. Introduction to Reservoir Simulation. In Principles of Applied Reservoir Simulation, 4th ed.; Gulf Professional Publishing: Houston, TX, USA, 2018; pp. 1-8. 
4. Agosta, F.; Alessandroni, M.; Antonellini, M.; Tondi, E.; Giorgioni, M. From fractures to flow: A field-based quantitative analysis of an outcropping carbonate reservoir. Tectonophysics 2010, 490, 197-213. [CrossRef]

5. Garland, J.; Neilson, J.E.; Laubach, S.E.; Whidden, K.J. Advances in carbonate exploration and reservoir analysis. In Advances in Carbonate Exploration and Reservoir Analysis; Garland, J., Neilson, J.E., Laubach, S.E., Whidden, K.J., Eds.; Geological Society of London: London, UK, 2012; Volume 370, pp. 1-15.

6. Lavenu, A.P.C.; Lamarche, J.; Gallois, A.; Gauthier, B.D.M. Tectonic versus diagenetic origin of fractures in a naturally fractured carbonate reservoir analog (Nerthe anticline, southeastern France). AAPG Bull. 2013, 97, 2207-2232. [CrossRef]

7. Amoroso, O.; Ascione, A.; Mazzoli, S.; Virieux, J.; Zollo, A. Seismic imaging of a fluid storage in the actively extending Apennine mountain belt, southern Italy. Geophys. Res. Lett. 2014, 41, 3802-3809. [CrossRef]

8. Korneva, I.; Cilona, A.; Tondi, E.; Agosta, F.; Giorgioni, M. Characterisation of the permeability anisotropy of Cretaceous platform carbonates by using 3D fracture modeling: The case study of Agri Valley fault zones (southern Italy). Ital. J. Geosci. 2015, 134, 396-408. [CrossRef]

9. Guo, X.; Feng, Q.; Liu, W.; Li, Z.; Wen, X.; Si, J.; Xi, H.; Guo, R.; Jia, B. Stable isotopic and geochemical identification of groundwater evolution and recharge sources in the arid Shule River Basin of Northwestern China. Hydrol. Process. 2015, 29, 4703-4718. [CrossRef]

10. Petrella, E.; Bucci, A.; Ogata, K.; Zanini, A.; Naclerio, G.; Chelli, A.; Francese, R.; Boschetti, T.; Pittalis, D.; Celico, F. Hydrodynamics in Evaporate-Bearing Fine-Grained Successions Investigated through an Interdisciplinary Approach: A Test Study in Southern Italy-Hydrogeological Behaviour of Heterogeneous Low-Permeability Media. Geofluids 2018, 2018, 5978597. [CrossRef]

11. Zanini, A.; Petrella, E.; Sanangelantoni, A.M.; Angelo, L.; Ventosi, B.; Viani, L.; Rizzo, P.; Remelli, S.; Bartoli, M.; Bolpagni, R.; et al. Groundwater characterisation from an ecological and human perspective: An interdisciplinary approach in the Functional Urban Area of Parma, Italy. Rend. Fis. Acc. Lincei 2019, 30, 93-108. [CrossRef]

12. Noble, R.T.; Lee, I.M.; Schiff, K.C. Inactivation of indicator micro-organisms from various sources of faecal contamination in seawater and freshwater. J. Appl. Microbiol. 2004, 96, 464-472. [CrossRef]

13. WHO. Guidelines for Drinking-Water Quality, 1st Addendum to, 3rd ed.; World Health Organization: New York, NY, USA, 2006.

14. Harvey, R.W.; George, L.H.; Smith, R.L.; LeBlanc, D.R. Transport of microspheres and indigenous bacteria through a sandy aquifer: Results of natural-and forced-gradient tracer experiments. Environ. Sci. Technol. 1989, 23, 51-56. [CrossRef]

15. Bucci, A.; Petrella, E.; Celico, F.; Naclerio, G. Use of molecular approaches in hydrogeological studies: The case of carbonate aquifers in southern Italy. Hydrogeol. J. 2017, 25, 1017-1031. [CrossRef]

16. Chapelle, F.H. Bioremediation of petroleum hydrocarbon-contaminated ground water: The perspectives of history and hydrology. Groundwater 1999, 37, 122-132. [CrossRef]

17. Samanta, S.K.; Singh, O.V.; Jain, R.K. Polycyclic aromatic hydrocarbons: Environmental pollution and bioremediation. Trends Biotechnol. 2002, 20, 243-248. [CrossRef]

18. Menendez-Vega, D.; Gallego, J.L.R.; Pelaez, A.I.; de Cordoba, G.F.; Moreno, J.; Muñoz, D.; Sanchez, J. Engineered in situ bioremediation of soil and groundwater polluted with weathered hydrocarbons. Eur. J. Soil Biol. 2007, 43, 310-321. [CrossRef]

19. Xu, X.; Liu, W.; Tian, S.; Wang, W.; Qi, Q.; Jiang, P.; Gao, X.; Li, F.; Li, H.; Yu, H. Petroleum hydrocarbon-degrading bacteria for the remediation of oil pollution under aerobic conditions: A perspective analysis. Front. Microbiol. 2018, 9, 2885. [CrossRef]

20. Li, X.-X.; Mbadinga, S.M.; Liu, J.-F.; Zhou, L.; Yang, S.-Z.; Gu, J.-D.; Mu, B.-Z. Microbiota and their affiliation with physiochemical characteristics of different subsurface petroleum reservoirs. Int. Biodeterior. Biodegradation 2017, 120, 170-185. [CrossRef]

21. Streit, W.R.; Schmitz, R.A. Metagenomics-the key to the uncultured microbes. Curr. Opin. Microbiol. 2004, 7, 492-498. [CrossRef]

22. Chen, L.; Wang, L.-Y.; Liu, S.-J.; Hu, J.-Y.; He, Y.; Zhou, H.-W.; Zhang, X.-H. Profiling of microbial community during in situ remediation of volatile sulfide compounds in river sediment with nitrate by high throughput sequencing. Int. Biodeterior. Biodegrad. 2013, 85, 429-437. [CrossRef] 
23. Kucharzyk, K.H.; Rectanus, H.V.; Bartling, C.M.; Rosansky, S.; Minard-Smith, A.; Mullins, L.A.; Neil, K. Use of omic tools to assess methyl tert-butyl ether (MTBE) degradation in groundwater. J. Hazard. Mater. 2019, 378, 120618. [CrossRef]

24. Giano, S.I.; Maschio, L.; Alessio, M.; Ferranti, L.; Improta, S.; Schiattarella, M. Radiocarbon dating of active faulting in the Agri high valley, southern Italy. J. Geodyn. 2000, 29, 371-386. [CrossRef]

25. D'Addezio, G.; Karner, D.B.; Burrato, P.; Insinga, D.; Maschio, L.; Ferranti, L.; Renne, P.R. Tephrochronology in faulted Middle Pleistocene tephra layer in the Val d'Agri area (Southern Italy). Ann. Geophys. 2006, $49,1029-1040$.

26. Giocoli, A.; Stabile, T.A.; Adurno, I.; Perrone, A.; Gallipoli, M.R.; Gueguen, E.; Norelli, E.; Piscitelli, S. Geological and geophysical characterisation of the southeastern side of the High Agri Valley (southern Apennines, Italy). Nat. Hazards Earth Syst. Sci. 2015, 15, 315-323. [CrossRef]

27. Patacca, E.; Scandone, P.; Bellatalla, M.; Perilli, N.; Santini, U. The Numidian-sand event in the Southern Apennines. Mem. Sci. Geol. Padova 1992, 43, 297-337.

28. Merlini, S.; Mostardini, F. Appennino centro-meridionale: Sezioni geologiche e proposta di modello strutturale. Mem. Soc. Geol. It. 1986, 35, 177-202.

29. Butler, R.W.H.; Corrado, S.; Mazzoli, S.; De Donatis, M.; Di Bucci, D.; Naso, G.; Scrocca, D.; Nicolai, C.; Zucconi, V. Time and space variability of «thin-skinned» and «thick-skinned» thrust tectonics in the Apennines (Italy). Rend. Fis. Acc. Lincei 2000, 11, 5-39. [CrossRef]

30. Menardi Noguera, A.; Rea, G. Deep structure of the Campanian-Lucanian arc (southern Apennine, Italy). Tectonophysics 2000, 324, 239-265. [CrossRef]

31. Wavrek, D.A.; Mosca, F. Compositional grading in the oil column: Advances from a mass balance and quantitative molecular analysis. In Understanding Petroleum Reservoirs: Towards an Integrated Reservoir Engineering and Geochemical Approach; Cubitt, J.M., England, W.A., Larter, S.R., Eds.; Geological Society of London: London, UK, 2004; Volume 237, pp. 207-220.

32. Cazzini, F.F. The history of the upstream oil and gas industry in Italy. In History of the European Oil and Gas Industry; Craig, J., Gerali, F., MacAulay, F., Sorkhabi, R., Eds.; Geological Society Special Publications: London, UK, 2018; Volume 465, pp. 243-274.

33. Olita, F. Investigation of the natural hydrocarbon manifestations and 3D reconstruction of the reservoir in the Tramutola area (Basilicata). Master's thesis, University of Basilicata, Potenza, Italy, 2019.

34. Scandone, P.; Sgrosso, I. Flysch con Inocerami nella valle del Cavolo presso Tramutola (Lucania). Boll. Soc. Nat. Napoli 1964, 73, 166-175.

35. Mattioni, L.; Tondi, E.; Shiner, P.; Renda, P.; Vitale, S.; Cello, G. The Argille Varicolori unit in Lucania (Italy): A record of tectonic offscraping and gravity sliding in the Mesozoic-Tertiary Lagonegro Basin, southern Apennines. In Tectonics of the Western Mediterranean and North Africa; Moratti, G., Chalouan, A., Eds.; Geological Society of London: London, UK, 2006; Volume 262, pp. 277-288.

36. Scandone, P. Studi di geologia lucana: La serie calcareo-silico-marnosa e i suoi rapporti con l'Appennino calcareo. Boll. Soc. Nat. Napoli 1967, 76, 1-175.

37. Scandone, P. Studi di geologia lucana: Note illustrative della carta dei terreni della serie calcareo-silico-marnosa. Boll. Soc. Nat. Napoli 1972, 81, 225-300.

38. De Vita, P.; Allocca, V.; Celico, F.; Fabbrocino, S.; Cesaria, M.; Monacelli, G.; Musilli, I.; Piscopo, V.; Scalise, A.R.; Summa, G.; et al. Hydrogeology of continental Southern Italy. J. Maps 2018, 14, 230-241.

39. Berserzio, R.; Felletti, F.; Giudici, M.; Miceli, A.; Zembo, I. Aquifer analogues to assist modeling of groundwater flow: The Pleistocene aquifer complex of the Agri Valley (Basilicata). In Proceedings Italian National Workshop "Developments in Aquifer Sedimentology and Ground Water Flow Studies in Italy; Ist. Poligrafico e Zecca dello Stato: Roma, Italy, 2007; pp. 51-66.

40. Petrella, E.; Celico, F. Heterogeneous aquitard properties in sedimentary successions in the Apennine chain: Case studies in southern Italy. Hydrol. Process. 2009, 23, 3365-3371. [CrossRef]

41. Petrella, E.; Celico, F. Mixing of water in a carbonate aquifer, southern Italy, analysed through stable isotope investigations. Int. J. Speleol. 2013, 42, 25-33. [CrossRef]

42. De Vita, P.; Allocca, V.; Manna, F.; Fabbrocino, S. Coupled decadal variability of the North Atlantic Oscillation, regional rainfall and karst spring discharges in the Campania region (southern Italy). Hydrol. Earth Sys. Sci. 2012, 16, 1389-1399. [CrossRef] 
43. Allocca, V.; De Vita, P.; Manna, F.; Nimmo, J.R. Groundwater recharge assessment at local and episodic scale in a soil mantled perched karst aquifer in southern Italy. J. Hydrol. 2015, 529, 843-853. [CrossRef]

44. Fiorillo, F.; Esposito, L.; Testa, G.; Ciarcia, S.; Pagnozzi, M. The upwelling water flux feeding springs: Hydrogeological and hydraulic features. Water 2018, 10, 501. [CrossRef]

45. Fiorillo, F.; Leone, G.; Pagnozzi, M.; Catani, V.; Testa, G.; Esposito, L. The upwelling groundwater flow in the karst area of Grassano-Telese springs (Southern Italy). Water 2019, 11, 872. [CrossRef]

46. Paternoster, M.; Scarfiglieri, A.; Mongelli, G. Groundwater chemistry in the high Agri Valley (Southern Apennines, Italy). GeoActa 2005, 4, 25-42.

47. International Atomic Energy Agency. Water and Environment News, Issue 3, IAEA: Vienna, Austria, April 1998.

48. U.S. EPA. Method 3510C (SW-846): Separatory Funnel Liquid-Liquid Extraction; U.S. Environmental Protection Agency: Washington, DC, USA, 1996.

49. U.S. EPA. Method 5030C (SW-846): Purge-and-Trap for Aqueous Samples Revision 3; U.S. Environmental Protection Agency: Washington, DC, USA, 2003.

50. U.S. EPA. Method 8015D (SW-846): Nonhalogenated Organics Using GC/FID Revision 4; U.S. Environmental Protection Agency: Washington, DC, USA, 2003.

51. U.S. EPA. Method 8270E (SW-846): Semivolatile Organic Compounds by Gas Chromatography/Mass Spectrometry (GC/MS); U.S. Environmental Protection Agency: Washington, DC, USA, 2018.

52. Milani, C.; Hevia, A.; Foroni, E.; Duranti, S.; Turroni, F.; Lugli, G.A.; Sanchez, B.; Martín, R.; Gueimonde, M.; van Sinderen, D.; et al. Assessing the fecal microbiota: An optimised ion torrent 16S rRNA gene-based analysis protocol. PLoS ONE 2013, 8, e68739. [CrossRef]

53. Caporaso, J.G.; Kuczynski, J.; Stombaugh, J.; Bittinger, K.; Bushman, F.D.; Costello, E.K.; Fierer, N.; Gonzalez Peña, A.; Goodrich, J.K.; Gordon, J.I.; et al. QIIME allows analysis of high-throughput community sequencing data. Nat. Methods 2010, 7, 335-336. [CrossRef]

54. Callahan, B.J.; McMurdie, P.J.; Rosen, M.J.; Han, A.W.; Johnson, A.J.; Holmes, S.P. DADA2: High-resolution sample inference from Illumina amplicon data. Nat. Methods 2016, 13, 581-583. [CrossRef]

55. Bokulich, N.A.; Kaehler, B.D.; Rideout, J.R.; Dillon, M.; Bolyen, E.; Knight, R.; Huttley, G.A.; Caporaso, J.G. Optimising taxonomic classification of marker-gene amplicon sequences with QIIME 2's q2-feature-classifier plugin. Microbiome 2018, 6, 90. [CrossRef] [PubMed]

56. Quast, C.; Pruesse, E.; Yilmaz, P.; Gerken, J.; Schweer, T.; Yarza, P.; Peplies, J.; Glöckner, F.O. The SILVA ribosomal RNA gene database project: Improved data processing and web-based tools. Nucleic Acids Res. 2013, 41, D590-D596. [CrossRef] [PubMed]

57. Longinelli, A.; Selmo, E. Isotopic composition of precipitation in Italy: A first overall map. J. Hydrol. 2003, 270, 75-88.

58. Zar, J.H. Biostatistical Analysis, 5th ed.; Prentice Hall, Inc.: Englewood Cliffs, NJ, USA, 2010.

59. Petrella, E.; Naclerio, G.; Falasca, A.; Bucci, A.; Capuano, P.; De Felice, V.; Celico, F. Non-permanent shallow halocline in a fractured carbonate aquifer, southern Italy. J. Hydrol. 2009, 373, 267-272. [CrossRef]

60. Krajcar Bronić, I.; Barešić, J.; Borković, D.; Sironić, A.; Mikelić, I.L.; Vreča, P. Long-Term Isotope Records of Precipitation in Zagreb, Croatia. Water 2020, 12, 226. [CrossRef]

61. Auling, G.; Busse, H.-J.; Egli, T.; El-Banna, T.; Stackebrandt, E. Description of the Gram-negative, obligately aerobic, nitrilotriacetate (NTA)-utilizing bacteria as Chelatobacter heintzii, gen. nov., sp. nov., and Chelatococcus asaccharovorans, gen. nov., sp. nov. Syst. Appl. Microbiol. 1993, 16, 104-112. [CrossRef]

62. Mahe, Y.F.; Perez, M.J.; Tacheau, C.; Fanchon, C.; Martin, R.; Rousset, F.; Seite, S. A new Vitreoscilla filiformis extract grown on spa water-enriched medium activates endogenous cutaneous antioxidant and antimicrobial defenses through a potential Toll-like receptor 2/protein kinase C, zeta transduction pathway. Clin. Cosmet. Investig Dermatol. 2013, 6, 191-196.

63. Palleroni, N.J. New species of the genus Actinoplanes, Actinoplanes ferrugineus. Int. J. Syst. Evol. Microbiol. 1979, 29, 51-55. [CrossRef]

64. Pellegrin, V.; Juretschko, S.; Wagner, M.; Cottenceau, G. Morphological and biochemical properties of a Sphaerotilus sp. isolated from paper mill slimes. Appl. Environ. Microbiol. 1999, 65, 156-162. [CrossRef] 
65. Willems, A.; Busse, J.; Goor, M.; Pot, B.; Falsen, E.; Jantzen, E.; Hoste, B.; Gillis, M.; Kersters, K.; Auling, G.; et al. Hydrogenophaga, a new genus of hydrogen-oxidizing bacteria that includes Hydrogenophaga flava comb. nov.(formerly Pseudomonas flava), Hydrogenophaga palleronii (formerly Pseudomonas palleronii), Hydrogenophaga pseudoflava (formerly Pseudomonas pseudoflava and "Pseudomonas carboxydoflava"), and Hydrogenophaga taeniospiralis (formerly Pseudomonas taeniospiralis). Int. J. Syst. Evol. Microbiol. 1989, 39, 319-333.

66. Zhang, Y.-Q.; Chen, Y.-G.; Li, W.-J.; Tian, X.-P.; Xu, L.-H.; Jiang, C.-L. Sphingomonas yunnanensis sp. nov., a novel Gram-negative bacterium from a contaminated plate. Int. J. Syst. Evol. Microbiol. 2005, 55, 2361-2364. [PubMed]

67. Van Niel, C.B. On the morphology and physiology of the purple and green sulphur bacteria. Archiv. Mikrobiol. 1932, 3, 1-112. [CrossRef]

68. Rees, G.N.; Patel, B.K.; Grassia, G.S.; Sheehy, A.J. Anaerobaculum thermoterrenum gen. nov., sp. nov., a novel, thermophilic bacterium which ferments citrate. Int. J. Syst. Bacteriol. 1997, 47, 150-154. [CrossRef] [PubMed]

69. Thevenieau, F.; Fardeau, M.L.; Ollivier, B.; Joulian, C.; Baena, S. Desulfomicrobium thermophilum sp. nov., a novel thermophilic sulphate-reducing bacterium isolated from a terrestrial hot spring in Colombia. Extremophiles 2007, 11, 295-303. [CrossRef] [PubMed]

70. Chimtong, S.; Tachaapaikoon, C.; Pason, P.; Kyu, K.L.; Kosugi, A.; Mori, Y.; Ratanakhanokchai, K. Isolation and characterization of endocellulase-free multienzyme complex from newly isolated Thermoanaerobacterium thermosaccharolyticum strain NOI-1. J. Microbiol. Biotechnol. 2011, 21, 284-292. [CrossRef] [PubMed]

71. Wiegel, J.; Ljungdahl, L.G. Thermoanaerobacter ethanolicus gen. nov., spec. nov., a new, extreme thermophilic, anaerobic bacterium. Arch. Microbiol. 1981, 128, 343-348. [CrossRef]

72. Knøchel, S. Growth characteristics of motile Aeromonas spp. isolated from different environments. Int. J. Food Microbiol. 1990, 10, 235-244. [CrossRef]

73. Horn, M.A.; Ihssen, J.; Matthies, C.; Schramm, A.; Acker, G.; Drake, H.L. Dechloromonas denitrificans sp. nov., Flavobacterium denitrificans sp. nov., Paenibacillus anaericanus sp. nov. and Paenibacillus terrae strain MH72, $\mathrm{N} 2 \mathrm{O}$-producing bacteria isolated from the gut of the earthworm Aporrectodea caliginosa. Int. J. Syst. Evol. Microbiol. 2005, 55, 1255-1265. [CrossRef]

74. Bernardet, J.-F.; Bowman, J.P. Flavobacterium. In Bergey's Manual of Systematics of Archaea and Bacteria; Whitman, W.B., Rainey, F., Kämpfer, P., Trujillo, M., Chun, J., DeVos, P., Hedlund, B., Dedysh, S., Eds.; John Wiley \& Sons, Inc., in association with Bergey's Manual Trust: Hoboken, NJ, USA, 2015.

75. Spring, S.; Kampfer, P.; Ludwig, W.; Schleifer, K.-H. Polyphasic characterization of the genus Leptothrix: New descriptions of Leptothrix mobilis sp. nov. and Leptothrix discophora sp. nov. nom. rev. and emended description of Leptothrix cholodnii emend. Syst. Appl. Microbiol. 1996, 19, 634-643. [CrossRef]

76. Kalyuzhnaya, M.G.; Bowerman, S.; Lara, J.C.; Lidstrom, M.E.; Chistoserdova, L. Methylotenera mobilis gen. nov., sp. nov., an obligately methylamine-utilising bacterium within the family Methylophilaceae. Int. J. Syst. Evol. Microbiol. 2006, 56, 2819-2823. [CrossRef]

77. Zhang, J.; Song, F.; Xin, Y.H.; Zhang, J.; Fang, C. Microvirga guangxiensis sp. nov., a novel alphaproteobacterium from soil, and emended description of the genus Microvirga. Int. J. Syst. Evol. Microbiol. 2009, 59, 1997-2001. [CrossRef] [PubMed]

78. Kodama, Y.; Watanabe, K. Sulfuricurvum kujiense gen. nov., sp. nov., a facultatively anaerobic, chemolithoautotrophic, sulfur-oxidising bacterium isolated from an underground crude-oil storage cavity. Int. J. Syst. Evol. Microbiol. 2004, 54, 2297-2300. [CrossRef] [PubMed]

79. Kojima, H.; Fukui, M. Sulfuritalea hydrogenivorans gen. nov., sp. nov., a facultative autotroph isolated from a freshwater lake. Int. J. Syst. Evol. Microbiol. 2011, 61, 1651-1655. [CrossRef] [PubMed]

80. Inagaki, F.; Takai, K.; Nealson, K.H.; Horikoshi, K. Sulfurovum lithotrophicum gen. nov., sp. nov., a novel sulfur-oxidising chemolithoautotroph within the $\varepsilon$-Proteobacteria isolated from Okinawa Trough hydrothermal sediments. Int. J. Syst. Evol. Microbiol. 2004, 54, 1477-1482. [CrossRef]

81. Ito, T.; Sugita, K.; Yumoto, I.; Nodasaka, Y.; Okabe, S. Thiovirga sulfuroxydans gen. nov., sp. nov., a chemolithoautotrophic sulfur-oxidising bacterium isolated from a microaerobic waste-water biofilm. Int. J. Syst. Evol. Microbiol. 2005, 55, 1059-1064. [CrossRef]

82. Aruga, S.; Kamagata, Y.; Kohno, T.; Hanada, S.; Nakamura, K.; Kanagawa, T. Characterisation of filamentous Eikelboom type $021 \mathrm{~N}$ bacteria and description of Thiothrix disciformis sp. nov. and Thiothrix flexilis sp. nov. Int. J. Syst. Evol. Microbiol. 2002, 52, 1309-1316. 
83. Storti, F.; Billi, A.; Salvini, F. Particle size distributions in natural carbonate fault rocks: Insights for non-self-similar cataclasis. Earth Planet. Sci. Lett. 2003, 206, 173-186. [CrossRef]

84. Ferraro, F.; Grieco, D.S.; Agosta, F.; Prosser, G. Space-time evolution of cataclasis in carbonate fault zones. J. Struct. Geol. 2018, 110, 45-64. [CrossRef]

85. Giuffrida, A.; La Bruna, V.; Castelluccio, P.; Panza, E.; Rustichelli, A.; Tondi, E.; Giorgioni, M.; Agosta, F. Fracture simulation parameters of fractured reservoirs: Analogy with outcropping carbonates of the Inner Apulian Platform, southern Italy. J. Struct. Geol. 2019, 123, 18-41. [CrossRef]

86. Chiodini, G.; Avino, R.; Brombach, T.; Caliro, S.; Cardellini, C.; De Vita, S.; Frondini, F.; Granirei, D.; Marotta, E.; Ventura, G. Fumarolic and diffuse soil degassing west of Mount Epomeo, Ischia, Italy. J. Volcanol. Geotherm. Res. 2004, 133, 291-309. [CrossRef]

87. Celico, F.; Petrella, E.; Celico, P. Hydrogeological behaviour of some fault zones in a carbonate aquifer of Southern Italy: An experimentally based model. Terra Nova 2006, 18, 308-313. [CrossRef]

88. Petrella, E.; Capuano, P.; Carcione, M.; Celico, F. A high-altitude temporary spring in a compartmentalised carbonate aquifer: The role of low-permeability faults and karst conduits. Hydrol. Process. 2009, 23, 3354-3364. [CrossRef]

89. Bucci, A.; Naclerio, G.; Allocca, V.; Celico, P.; Celico, F. Potential use of microbial community investigations to analyse hydrothermal systems behaviour: The case of Ischia Island, Southern Italy. Hydrol. Process. 2011, 25, 1866-1873. [CrossRef]

90. Bucci, A.; Petrella, E.; Naclerio, G.; Gambatese, S.; Celico, F. Bacterial migration through low-permeability fault zones in compartmentalised aquifer systems: A case study in Southern Italy. Int. J. Speleol. 2014, 43, 273-281. [CrossRef]

91. Aquino, D.; Petrella, E.; Florio, M.; Celico, P.; Celico, F. Complex hydraulic interactions between compartmentalised carbonate aquifers and heterogeneous siliciclastic successions: A case study in southern Italy. Hydrol. Process. 2015, 29, 4252-4263. [CrossRef]

92. Petrella, E.; Aquino, D.; Fiorillo, F.; Celico, F. The effect of low-permeability fault zones on groundwater flow in a compartmentalised system. Experimental evidence from a carbonate aquifer (Southern Italy). Hydrol. Process. 2015, 29, 1577-1587. [CrossRef]

93. Allocca, V.; Marzano, E.; Tramontano, M.; Celico, F. Environmental impact of cattle grazing on a karst aquifer in the southern Apennines (Italy): Quantification through the grey water footprint. Ecol. Indic. 2018, 93, 830-837. [CrossRef]

94. Pekdeger, A.; Matthess, G. Factors of bacteria and virus transport in groundwater. Environ. Geol. 1983, 5, 49-52. [CrossRef]

95. McMurry, S.W.; Coyne, M.S.; Perfect, E. Fecal coliform transport through intact soil blocks amended with poultry manure. J. Environ. Qual. 1998, 27, 86-92. [CrossRef]

96. Naclerio, G.; Fardella, G.; Marzullo, G.; Celico, F. Filtration of Bacillus subtilis and Bacillus cereus spores in a pyroclastic topsoil, carbonate Apennines, southern Italy. Colloids Surf. B Biointerfaces 2009, 70, 25-28. [CrossRef]

97. Bucci, A.; Petrella, E.; Naclerio, G.; Allocca, V.; Celico, F. Microorganisms as contaminants and natural tracers: A 10-year research in some carbonate aquifers (southern Italy). Environ. Earth Sci. 2015, 74, 173-184. [CrossRef]

98. Candela, S.; Mazzoli, S.; Megna, A.; Santini, S. Finite element modelling of stress field perturbations and interseismic crustal deformation in the Val d'Agri region, southern Apennines, Italy. Tectonophysics 2015, 657, 245-259. [CrossRef]

(C) 2020 by the authors. Licensee MDPI, Basel, Switzerland. This article is an open access article distributed under the terms and conditions of the Creative Commons Attribution (CC BY) license (http://creativecommons.org/licenses/by/4.0/). 